\title{
PEMBELAJARAN BERBASIS PROYEK PADA KONSEP KOLOID UNTUK PENGEMBANGAN KETERAMPILAN PROSES SAINS SISWA
}

\author{
Evi Sapinatul Bahriah ${ }^{1}$, Siti Suryaningsih ${ }^{1}$ dan Dewi Yuniati ${ }^{1}$ \\ ${ }^{1}$ Pendidikan Kimia Fakultas IImu Tarbiyah dan Keguruan UIN Syarif Hidayatullah \\ J.. Ir. H. Juanda No. 95 Ciputat Jakarta 15412 Indonesia \\ E-mail: evi@uinjkt.ac.id
}

\begin{abstract}
ABSTRAK
Telah dilakukan penelitian yang bertujuan untuk menelusuri keterampilan proses sains siswa yang dikembangkan oleh guru pada konsep koloid melalui pembelajaran berbasis proyek. Penelitian ini melibatkan subyek penelitian sebanyak 35 siswa. Data-data diperoleh dari lembar observasi pembelajaran untuk mengetahui keterampilan proses sains yang dikembangkan siswa dan angket yang digunakan untuk menjaring respon siswa terhadap pembelajaran. Data yang telah diperoleh kemudian dianalisis secara deskriptif. Hasil dari penelitian ini menunjukan bahwa siswa telah memiliki semua indikator keterampilan proses sains yang termasuk kategori baik (nilai rerata 78,41 ). Siswa memberikan respon yang positif terhadap pembelajaran, karena merasa lebih paham, meningkatkan motivasi dan minat belajar.
\end{abstract}

Kata kunci: pembelajaran berbasis proyek, keterampilan proses sains, koloid

\begin{abstract}
A research aimed to explore students' science process skills in colloid concept through project-based learning. This research involved 35 research subjects. The data obtained from observation sheets learning to know the science process skills developed by students and questionnaires were used to collect the students' response to learning. The data are analyzed descriptively. Results from this study showed that the students had all the indicators of science process skills with good value (average value 78.41). Students give a positive response to learning, because they feel more understanding, increase motivation and interest in learning.
\end{abstract}

Keywords: project based learning, students science process skills, colloid

DOI: https://doi.org/10.15575/jtk.v2i2.1883

\section{PENDAHULUAN}

Perubahan cepat dalam sains dan teknologi akhir-akhir ini telah mempengaruhi Pendidikan. Pendidikan sains memerankan peran penting dalam masa depan. Secara global, negara terus berupaya dalam meningkatkan kualitas pendidikan sains khususnya di negara berkembang (Rauf, et.al, 2013). Pendidikan sains sangat penting untuk diajarkan di sekolah dan dikuasai oleh peserta didik. Pentingnya pendidikan sains di sekolah bukan hanya berpusat pada dunia, namun penting juga dalam pengembangan teknologi dalam membentuk sikap ilmiah, meningkatkan keterampilan dan memberikan kesempatan bagi peserta didik dalam pembangunan budaya masyarakat (Sukarno, dkk, 2013).

Oleh karena itu, siswa saat ini harus bisa beradaptasi dengan perubahan dunia teknologi yang berkembang. Selain itu, sistem pendidikan perlu dimodifikasi agar siswa dapat mengaktifkan cara belajar mereka untuk mencapai pengetahuan, untuk mengembangkan solusi untuk menyelesaikan masalah yang belum diketahui dan untuk 
meningkatkan keterampilan yang dimiliki oleh siswa (Ince Aka, et al, 2010).

Namun kenyataannya masih banyak keterampilan proses siswa yang masih belum muncul pada saat proses pembelajaran berlangsung. Kebanyakan sekolah yang hanya menekankan penguasaan konsep, serta kegiatan pembelajaran yang belum mengeksplorasi keterampilan proses sains siswa pada proses pembelajaran (Sukarno, dkk, 2013). Berdasarkan observasi yang dilakukan pada salah satu sekolah di Jakarta menunjukkan bahwa keterampilan proses sains siswa masih rendah. Rendahnya keterampilan proses sains yang dimiliki oleh peserta didik disebabkan oleh beberapa faktor yang menyebabkan keterampilan siswa tidak muncul. Sesuai dengan penelitian yang telah dilakukan oleh Jack (2013) ada dua faktor yang menyebabkan keterampilan proses sains rendah yaitu rendahnya latar belakang sains dan minimnya prasarana laboratorium. Untuk mencapai tujuan pembelajaran, peserta didik dan guru harus mencari tahu faktor, inovasi dan cara dalam memperbaiki, memodifikasi, menambah atau mengganti metode yang dapat memberikan pembelajaran yang efektif dan berarti pada setiap proses pembelajarannya. Oleh karena itu, perlu diupayakan proses pembelajaran yang dapat mengiringi perubahan, lebih mengaktifkan dan memotivasi siswa untuk mengembangkan daya nalarnya dalam merencanakan dan menyelesaikan persoalan yang dihadapi melalui pemberian pengalaman langsung dengan melakukan serangkaian proses sains. Pembelajaran berbasis proyek diharapkan dapat meningkatkan keterampilan proses sains siswa yang lebih baik dari sebelumnya.

Pembelajaran berbasis proyek lebih memfokuskan pada pengkonstruksian pengetahuan siswa, di mana siswa diharapkan dapat menemukan informasi penting dalam mengkonstruksi pengetahuan sendiri (Siwa, dkk., 2013). Selain itu, pembelajaran berbasis proyek merupakan tugas-tugas kompleks yang didasarkan pada pertanyaan-pertanyaan yang menantang atau permasalahan yang melibatkan para siswa dalam desain, pemecahan masalah, pengambilan keputusan atau aktivitas investigasi, memberi peluang siswa untuk bekerja secara otonomi dengan periode waktu yang lama dan akhirnya menghasilkan produk-produk yang nyata atau presentasipresentasi (Fitrina, dkk 2016).

Berdasarkan penelitian yang dilakukan oleh Omar, dkk (2014) dan Tasiwan (2015) pembelajaran berbasis proyek adalah pembelajaran yang efektif untuk mengembangkan keterampilan proses sains dan sikap sains siswa. Selain itu sesuai dengan penelitian Çakici dan Türkmen (2013) siswa yang melaksanakan kegiatan berbasis proyek akan memiliki hasil belajar yang lebih signifikan dibandingkan mereka yang menggunakan pembelajaran regular. Hal tersebut, karena pembelajaran berbasis proyek efektif untuk memotivasi siswa dalam membuat strategi, meningkatkan tanggung jawab untuk guru dalam memberikan ilmu sehingga lebih menyenangkan dan efektif. Pembelajaran yang berpusat pada siswa itu dapat menjadikan siswa lebih kritis, investigasi, komunikatif dan interaktif dalam melakukan eksperimen (Farida, et.al, 2017).

Menurut Kamdi (dalam Sutirman, 2013) pembelajaran berbasis proyek dianggap cocok sebagai suatu model untuk pendidikan yang merespon isu-isu peningkatan kualitas pendidikan kejuruan dan perubahanperubahan besar yang terjadi di dunia kerja. Pembelajaran berbasis proyek menekankan kegiatan belajar yang relatif berdurasi panjang, berpusat pada siswa dan terintegrasi dengan praktik dan isu-isu dunia nyata.

Koloid merupakan salah satu konsep kimia yang pembelajarannya dapat menggunakan pembelajaran berbasis proyek. Kompetensi dasar 4.14 (dalam Kurikulum Nasional) yaitu membuat berbagai sistem koloid dengan bahan-bahan yang ada di sekitarnya serta menganalisis sifat-sifat dari sistem koloid yang dibuat. Berdasarkan kompetensi dasar tersebut, siswa dituntut membuat suatu produk untuk dalam pembelajaran, dan dalam proses pembelajaran memungkinkan munculnya keterampilan proses sains. 


\section{METODE PENELITIAN}

Subyek penelitian yang diteliti adalah siswa kelas XI MIA 2 pada semester genap. Teknik pengumpulan data dalam penelitian ini adalah lembar observasi yang dilakukan untuk melihat keterampilan proses peserta didik yang muncul selama proses pembelajaran berlangsung dan lembar angket untuk memunculkan respon siswa mengenai penerapan pembelajaran berbasis proyek pada konsep koloid.

Data diperoleh dari lembar observasi berbentuk check list dan hasil lembar angket berbentuk skala likert. Selanjutnya dihitung persentase dari masing-masing indikator yang muncul data yang diperoleh diintepretasikan secara deskriptif untuk setiap indikator keterampilan proses sains yang muncul selama proses pembelajaran. Kualitas setiap indicator yang muncul dikategorikan sebagai berikut: $81-100 \%$ (sangat baik), 61-80 (baik), 41-60 (cukup), 2140 (kurang), dan 0-20 (sangat kurang).

\section{HASIL DAN PEMBAHASAN}

Berdasarkan hasil observasi pembelajaran,langkah-langkah pembelajaran yang dilakukan dan keterampilan proses yang muncul dalam pembelajaran sebagai berikut.

\subsection{Tahap Perencanaan Proyek (Project Planning)}

Pada proses pembelajaran, guru dan siswa membentuk kelompok sebagai sarana untuk bertukar pendapat selama proses pembelajaran berlangsung dan untuk pembuatan proyek. Kemudian, siswa diberikan wacana sehingga siswa dapat menemukan masalah yang akan didiskusikan dan dipecahkan. Selain itu, pada tahapan ini siswa merencanakan proyek yang akan dibuat dengan kelompok, pembagian tugas dengan anggota kelompok, mengumpulkan sumber belajar dan menentukan strategi untuk kelompok. Tahap ini juga ditujukan untuk menumbuhkan motivasi belajar siswa, memberikan pemahaman kepada siswa tentang tujuan yang dicapai dan menjelaskan kegiatan yang akan dilakukan. Pada tahapan ini keterampilan proses sains yang terlibat adalah hipotesis, prediksi, dan interpretasi.

Pada indikator prediksi mendapatkan nilai persentase sebesar 75 (baik). Ramalan berarti pula mengemukakan apa yang mungkin terjadi pada keadaan yang belum diamati berdasarkan penggunaan pola yang ditemukan sebagai hasil pengamatan (Putri, 2012). Aspek keterampilan prediksi mengalami peningkatan yang disebabkan karena nilai aspek keterampilan observasi yang tinggi (Putra, 2015). Hal ini disebabkan kemampuan prediksi sangat bergantung pada pengenalan fenomena yang merupakan bagian dari keterampilan observasi. Sifat keterampilan memprediksi ialah untuk dapat mengidentifikasi ciri-ciri di dalam kumpulan data kemudian memproyeksikan ciri-ciri tersebut dengan cara diuji (Sheeba, 2013).

Pada indikator interpretasi siswa mendapatkan nilai persentase sebesar 73,80 (baik). Pada indikator ini siswa dapat menyusun kesimpulan sesuai dan benar berdasarkan dari hasil percobaan yang telah dilakukan. Pada indikator ini siswa mampu menerjemahkan data-data, bukti-bukti dan petunjuk-petunjuk berdasarkan hasil pengamatan yang ada menjadi suatu kesimpulan. Siswa dikatakan mampu melakukan interpretasi dengan menggunakan informasi atau data yang diamati untuk membuat kesimpulan (Rauf, dkk., 2013).

\subsection{Tahap Validas Tahap Pelaksanaan Proyek (Project Launch)}

Tahapan di mana siswa menindaklanjuti pertanyaan-pertanyaan penuntun yang disampaikan oleh guru dengan merancang proyek yang akan dibuat, selain itu tahap ini juga disusun jadwal kegiatan untuk menyelesaikan proyek tersebut. Pada proses pembelajaran, guru memberikan contoh gambaran produk yang akan mereka buat, agar siswa menjadi termotivasi dan antusias dalam pembuatan proyek ini. Selain itu, pada 
tahapan ini guru memberi informasi kepada siswa tentang peraturan, prosedur, jadwal dan penilaian selama proses pembelajaran dalam pembuatan proyek. Pada tahapan ini keterampilan proses sains yang terlibat adalah mengajukan pertanyaan, merencanakan percobaan dan menggunakan alat dan bahan.

Pada indikator mengajukan pertanyaan mendapatkan persentase sebesar 51,66 (cukup). Selama proses pembelajaran berlangsung keterampilan mengajukan pertanyaan kurang muncul pada siswa. Hal ini dikarenakan siswa belum terlatih dalam mengajukan pertanyaan terutama untuk mengajukan pertanyaan yang berlatar belakang hipotesis. Siswa perlu diberikan stimulus dan dibimbing guru sehingga siswa mampu mengemukakan pertanyaannya. Keterampilan ini sulit muncul dan tergolong sulit diamati sehingga perlu dilatih secara kontinu untuk menjadikannya suatu kebiasaan baik bagi siswa (Ikhsan, 2016).

Pada indikator merencanakan percobaan mendapatkan nilai persentase sebesar 89,04 (sangat baik). Hal ini menunjukkan bahwa siswa sudah memiliki kemampuan untuk melakukan percobaan dan penyelidikan (Abel, 2016). Peningkatan ini terjadi dikarenakan pembelajaran model Project Based Learning yang menuntut siswa untuk mencari prosedur kerja dari buku, internet atau sumber lainnya dan siswa juga dituntut untuk merencanakan proyek bersama teman kelompok agar dalam pembuatan proyek siswa tidak mengalami kesulitan.

Pada indikator menggunakan alat dan bahan mendapatkan nilai sebesar 89,52 (sangat baik). Keterampilan menggunakan alat/bahan meliputi keterampilan memiliki alat-alat, mempersiapkan alat-alat, merangkai alat dan menggunakan alat untuk tujuan percobaan (Saputri, Masykuri, Ashadi \& Haryono, 2013). Dalam melakukan percobaan, siswa mampu menentukan alat-alat yang digunakan dalam percobaan dengan jumlah yang tepat.
3.3 Tahap Penemuan Terbimbing dan Pembuatan Produk (Guided Inquiry and Product Creation)

Pada tahap ini, siswa mengerjakan proyek yang telah dirancang sebelumnya, sesuai dengan jadwal yang telah disusun (Fiktoyana, Arsa, Adiarta, 2015), dengan hal ini pada tahapan sebelumnya siswa sudah menentukan produk koloid apa yang akan mereka buat bersama kelompok dan sudah mengetahui alat dan bahan apa saja yang akan mereka butuhkan dalam pembuatan proyek. Menurut Malik (2015) kegiatan eksperimen dapat menstimulus siswa untuk mengamati, memprediksi, dan merencanakan percobaan sehingga lebih terampil dalam menggunakan alat dan bahan, mengambil data dan menyimpulkan hasil percobaan. Pada tahapan ini keterampilan proses sains yang terlibat adalah observasi dan klasifikasi.

Pada indikator observasi mendapatkan persentase sebesar 90 dengan kategori sangat baik. Indikator mengamati merupakan keterampilan dasar bagi keterampilan proses lainnya yang menuntun siswa untuk menemukan pengalaman yang nyata dalam bentuk pemahaman konsep. Sesuai dengan yang dikemukakan oleh Katimi \& Ayani (2013), bahwa siswa yang melakukan observasi akan lebih mudah dalam menangkap apa yang mereka lihat dibandingkan dengan menghafal suatu materi. Selain itu keterampilan mengamati merupakan keterampilan yang lebih mudah muncul dibandingkan kesembilan indikator lainnya (Zeidan \& Jayosi, 2015). Terlihat dalam kelompoknya siswa saling berdiskusi tentang pengamatan yang mereka dapatkan, sehingga pengamatan didapat secara maksimal.

Indikator mengamati menghasilkan capaian nilai yang tinggi. Hal ini berdampak positif terhadap peningkatan indikator mengklasifikasi siswa. Sesuai dengan yang dikemukakan oleh Santosari (2015) bahwa capaian tiap indikator keterampilan proses sains berkaitan satu sama lain. Hasil capaian nilai keterampilan mengamati yang tinggi mempengaruhi tingginya keterampilan 
mengklasifikasi. Hal ini disebabkan siswa yang melakukan pengamatan dengan cermat menghasilkan keterampilan mengklasifikasi meningkat (Maradona, 2013).

\subsection{Kesimpulan Proyek (Project Conclusion)}

Pada tahap ini merupakan upaya yang dilakukan untuk menilai proses kegiatan dan hasil kerja proyek (Fiktoyana, Arsa, Adiarta, 2015). Oleh karena itu, pada proses pembelajaran siswa sudah harus mengumpulkan produk yang telah dibuat bersama teman kelompok sesuai dengan jadwal yang telah ditentukan oleh guru pada tahap perencanaan proyek. Selain itu, pada tahap ini siswa diharuskan presentasikan produk yang telah siswa buat bersama teman kelompoknya. Pada tahap ini peneliti dan observer menilai produk dan presentasi tiap kelompok sesuai kriteria yang telah peneliti tentukan. Menurut Muslim (2015) laporan percobaan dapat meningkatkan kinerja dan kemampuan komunikasi siswa, sehingga membantu siswa dalam membentuk pemahamannya. Pada tahapan ini keterampilan proses sains yang terlibat adalah menerapkan konsep dan berkomunikasi.

Pada indikator menerapkan konsep mendapatkan nilai persentase sebesar 78,33 dengan baik. Hal ini dikarenakan proses yang berulang mampu mengembangkan keterampilan siswa, terutama menerapkan konsep (Amelia, 2014) sehingga siswa mampu mengingat dan memahami apa yang dipelajari (Widayanto, 2009).

Pada indikator berkomunikasi mendapatkan nilai sebesar 83,40 dengan kategori sangat baik. Peningkatan ini terjadi dikarenakan siswa dituntut mampu mengkomunikasikan hasil percobaan yang mereka dapat baik secara lisan (pembuatan power point dan presentasikan di depan kelas) maupun tertulis melalui pembuatan laporan percobaan. Hal ini didukung dengan Tseng, Chang, Lou, Chen (2013) bahwa pembelajaran berbasis proyek adalah salah satu pembelajaran yang berfokus pada pengorganisasian belajar mandiri dalam proyek dengan melalui kegiatan diskusi dan kerja sama tim agar siswa mencapai target yang direncanakan.

Secara keseluruhan pencapaian keterampilan proses sains siswa dapat dilihat pada Gambar 1.

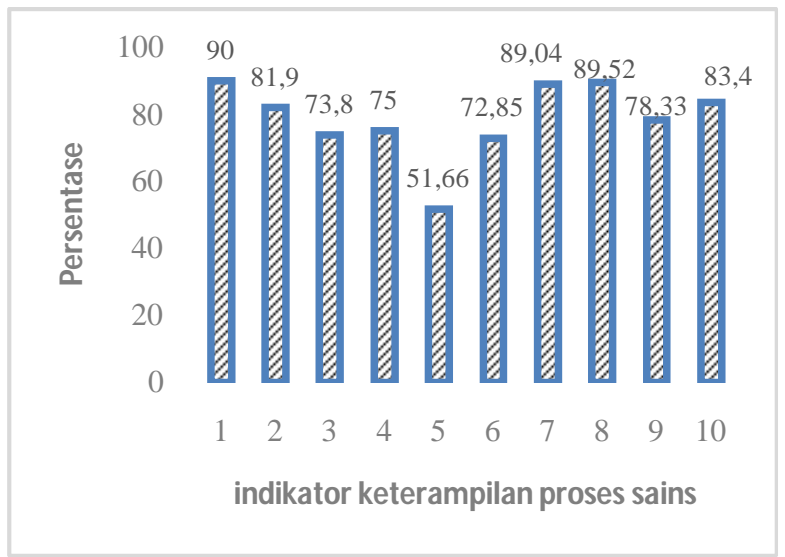

Keterangan: 1. Observasi; 2. Klasifikasi; 3. Interpretasi; 4. Prediksi; 5. Mengajukan Pertanyaan; 6. Hipotesis; 7. Merencanakan percobaan; 8. Menggunakan alat dan bahan; 9. Menerapkan konsep; 10. Berkomunikasi

\section{Gambar 1. Data Keterampilan Proses Sains Siswa Berdasarkan Indikator}

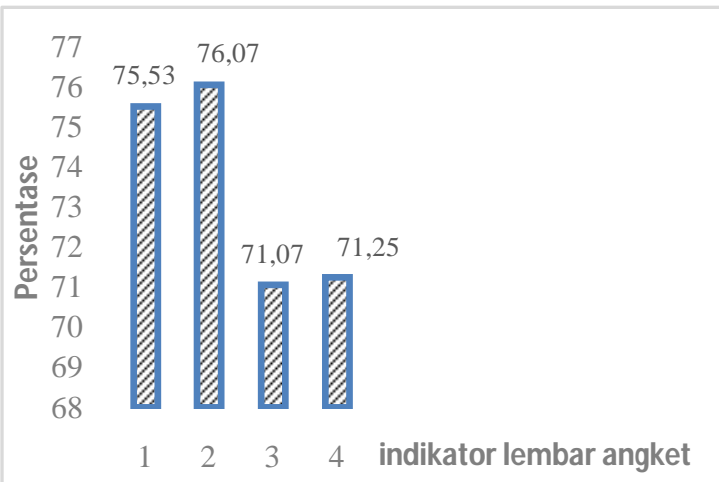

Keterangan: 1. Menunjukkan pemahaman siswa pada materi koloid; 2. Menunjukkan minat terhadap pembelajaran kimia pada materi koloid; 3. Memudahkan siswa dalam memahami materi koloid; 4. Mampu mengerjakan soal

\section{Gambar 2. Data Lembar Angket}

Berdasarkan penjelasan di atas, nilai data lembar observasi diperkuat dengan hasil lembar angket yang menyatakan respon siswa dalam kategori baik dengan nilai ratarata sebesar 73,48. Adapun indikator dari lembar angket adalah menunjukkan 
pemahaman siswa pada materi koloid, menunjukkan minat terhadap pembelajaran kimia pada materi koloid, memudahkan siswa dalam memahami materi koloid, dan mampu mengerjakan soal. Hal ini menunjukkan bahwa model project based learning dapat meingkatkan keterampilan proses sains siswa.

Berdasarkan penjelasan di atas, nilai data lembar observasi diperkuat dengan hasil lembar angket yang menyatakan respon siswa dalam kategori baik dengan nilai ratarata sebesar 73,48. Adapun indikator dari lembar angket adalah menunjukkan pemahaman siswa pada materi koloid, menunjukkan minat terhadap pembelajaran kimia pada materi koloid, memudahkan siswa dalam memahami materi koloid, dan mampu mengerjakan soal. Hal ini menunjukkan bahwa pembelajaran berbasis proyekdapat meningkatkan keterampilan proses sains siswa.

\section{KESIMPULAN}

Hasil dari penelitian ini menunjukan bahwa siswa telah memiliki semua indikator keterampilan proses sains yang termasuk kategori baik. Siswa memberikan respon yang positif terhadap pembelajaran, karena merasa lebih paham, meningkatkan motivasi dan minat belajar

Berdasarkan penelitian yang telah dilakukan, maka saran yang dapat diberikan yaitu: 1) Guru kimia hendaknya menerapkan pembelajaran berbasis proyek sebagai variasi model pembelajaran pada materi kimia lainnya; 2) Pelaksanaan pembelajaran berbasis proyek disarankan untuk lebih sering dilakukan karena dapat meningkatkan keterampilan proses sains ssiwa dengan catatan dilatih secara kontinu.

\section{DAFTAR PUSTAKA}

Abel, Triosa. (2016). Pengembangan Perangkat Praktikum Berbasis Biodiversitas Lokal Pada Materi Jamur Untuk Meningkatkan Keterampilan Proses Sains Siswa SMA. Jurnal
Pendidikan Guru Sekolah Dasar. 1(2). 30-35.

Amelia, Adhistia., Hartono \& Sri, D. Kartika. (2014). Penerapan Model Problem Based Instruction (PBI) untuk Meningkatkan Keterampilan Proses Sains di Sekolah Menengah Atas. Jurnal Penelitian Pendidikan Kimia, 1 (1), 1-8.

Çakici, Yilmaz., Türkmen, Nihal. (2013). An Investigation of The Effect of Project Based Learning Approach on Children's Achievement and Attitude in Science. The Online Journal of Science and Technology, 3(2).

Farida, I, Hadiansah, Mahmud \& A.Munandar. (2017). Project-based learning design for internalization of environmental literacy with islamic value. Journal Pendidikan IPA Indonesia, 6(2) : 277-284

Fiktoyana, Nyoman Haris., Arsa, I Putu Suka., Adiarta, Agus. (2015). Penerapan Model Project Based Learning untuk Meningkatkan Hasil Belajar Dasar dan Pengukuran Listrik Siswa Kelas X-TIPTL 3 Tahun Pelajaran 2014/2015 Di SMKN 3 Singaraja. Jurnal Pendidikan Teknik Elektro. 4(1). 1-12.

Fitrina, Ikhsan, Munzir, (2016). Peningkatan Kemampuan Berpikir Kreatif dan Komunikasi Matematis Siswa SMA melalui Model Pembelajaran Project Based Learning Berbasis Debat. Jurnal Didatik Matematika. 3(1), 2355-4185.

Ikhsan, Jaslin., Riyanningsih, Septi \& Sulistiowati. (2016). The Action For Improving Science Process Skill of Students' Through Scientific Approach and The Use ICT Support in Volumetric Analytical Chemistry at SMK - SMAK Bogor. International Conference on Educational Research and Innovation (ICERI 2016).

İnce Aka, E., Güven, E. \& Aydoğdu, M. (2010). Effect of problem solving method on science process skills and academic 
achievement. Journal of Turkish Science Education, 7(4), 13-25.

Jack, G. U. (2013). The Influence of Identified Student and School Variables on Student Science Process Skill Acquisition. Journal of Education and Practice. 4(5): 16-22.

Kartimi, Yulia. Ria., \& Ayani. (2013). Penerapan Pendekatan Keterampilan Proses dalam Pengajaran Biologi untuk Mengetahui Hasil Belajar Siswa pada Pokok Bahasan Ekosistem Kelas VII di SMPN 1 Talun. Jurnal Scientiae Educatia, 2 (1), 73-85.

Mahanal, S., Darmawan, E., Corebima, A. D., \& Zubaidah, S. (2012). Pengaruh Pembelajaran Project BasedLearning (PjBL) Pada Materi EkosistemTerhadap Sikap dan Keterampilan Proses SainsSiswa SMAN 2 Malang. Jurusan Biologi FMIPA Universitas Negeri Malang. Accessed in http://www.google.com/1_susriyati_univ .negeri_mal ang.pdf

Malik, A., Handayani, W., Nuraini, R. (2015). Model Praktikum Problem Solving Laboratory untuk Meningkatkan Keterampilan Proses Sains Mahasiswa. Prosiding Simposium Nasionaldan Pembelajaran Sains 2015 (SNIPS 2015), (hal. 193-196). Universitas Islam Negeri Sunan Gunung Djati Bandung.

Maradona. (2013). Analisis Keterampilan Proses Sains Siswa Kelas XI IPA SMA ISLAM Samarinda Pada Pokok Bahsan Hidrolisis Melalui Metode Eksperimen. Prosiding SeminarNasional Kimia 2013, (hal. 62-70).

Mihardi, S. (2013). Effect of Project Based Learning Model with KWL (Know-WantLearn) Worksheet on Creative Thinking in Solved Physics Problems. Thesis in State University of Medan (Unimed). Indonesia, Medan: Universitas Negeri Medan.
Muslim, Buchori. (2015). Pembelajaran Hidrolisis Garam Menggunakan Model Pembelajaran Pemecahan Masalah Tipe Gallet. Jurnal Penelitian dan Pembelajaran IPA (JPPI), 1 (1). 76- 90.

Omar, Romarzila., Puteh, Sharifah Nor., Ikhsan, Zanaton. (2014). Implementation of Science Skills Process in Project Based Learning Through Collaborative Action Research. ICER 2014.

Putra, Aditya Hadi Infantri., Widoretno, Sri., dan Adi, Baskoro. (2015). Peningkatan Keterampilan Proses Sains (KPS) Dasar Siswa Melalui Penerapan Model Learning Cycle 5E di Kelas VIII G SMP Negeri 22 Surakarta Tahun Pelajaran 2012/2013. Jurnal Pendidikan Biologi, 7(1), 89-100.

Putri dan Sutarno. (2012). Model Kegiatan Laboratorium Berbasis Problem Solving Pada Pembelajaran Gelombang dan Optik untuk Meningkatkan Keterampilan Proses Sains Mahasiswa. Jurnal Exacta. 10(2). 1412-3617.

Rahmawati, Putri Nur Laily., Muchtar, Imam \& Mardiati, Yayuk. (2014). Penerapan Metode Problem Solving untuk Meningkatkan Aktivitas dan Hasil Belajar Siswa Kelas V dalam Pembelajaran Pendidikan Kewarganegaraan Pokok Bahasan Menghargai Keputusan Bersama di SD Darul Hikmah Kranjingan Jember Tahun Pelajaran 2013/2014. Artikel IImiahMahasiswa UNEJ, (hal. 1 5). Universitas Negeri Jember.

Rauf, R. A., Lyndon, N., Mansor, A. N., Rasul, M. S., Othman, Z. (2013). Inculcation of Science Process Skills in a Science Classroom. Asian Social Science, 9 (8), 47-57.

Saputri, Masykuri, Ashadi, Haryono. (2013). Pembelajaran Kimia Berbasis Masalah Dengan Metode Proyek dan Eksperimen Ditinjau Dari Kreativitas dan Keterampilan Menggunakan Alat 
Laboratorium. Jurnal Inkuiri. 2 (3), 22527893.

Sheeba, M. N. (2013). An Anatomy of Science Process Skills in The Light of The Challenges to Realize Science Instruction Leading to Global Excellence in Education. Educationia Confab, 2 (4), 2320-009.

Siwa, IB., Muderawan, I. W., dan Tika, I.N. (2013). Pengaruh Pembelajaran Berbasis Proyek dalam Pembelajaran Kimia terhadap Keterampilan Proses Sains ditijau dari Gaya Kognitif Siswa. Singaraja: e-Journal Program Pascasarjana Universitas Pendidikan Ganesha, 3(2013).

Sukarno., Permanasari, A., \& Hamidah, I. (2013). The Profile of Science Process Skill (SPS) Student at Secondary High School (Case Study in Jambi). International Journal of Scientific Enginering andResearch. 1(1): 79-83.

Sutirman. (2013). Media dan Model-Model Pembelajaran Inovatif. Yogyakarta: Graha Ilmu.
Tasiwan. (2015). Efek Pembelajaran Berbasis Proyek Terbimbing Terhadap Perkembangan Keterampilan Proses dan Sikap Sains Siswa. Berkala Fisika Indonesia, 7(2).

Thomas, John.W. (2000). A Review of Research on Project-Based Learning. California: The Autodesk Foundation 111 Melnnis Paarkway.

Tseng, Kuo-Hung., dkk. (2011). Attitudes Toward Science, Technology, Engineering and Mathermatics (STEM) in a Project Based Learning (PjBL) Environment. J Technol Des Educ: Springer, 23, 87-102.

Widayanto. (2009). Pengembangan Keterampilan Proses dan Pemahaman Siswa Kelas X Melalui Kit Optik. Jurnal Pendidikan Fisika Indonesia, 5 (1), 1-9.

Zeidan, A. Hafez \& Jayosi, M. Rashed. (2015). Science Process Skills and Attitudes towards Science among Palestinian Secondary School Students. World Journal of Education, 5 (1), 13-24. 